\title{
Landscape analysis of the family planning situation in Pakistan-District profile: Lahore
}

Population Council

Follow this and additional works at: https://knowledgecommons.popcouncil.org/departments_sbsr-rh

Part of the Demography, Population, and Ecology Commons, Family, Life Course, and Society Commons, and the International Public Health Commons How does access to this work benefit you? Let us know!

\section{Recommended Citation}

"Landscape analysis of the family planning situation in Pakistan-District profile: Lahore." Islamabad: Population Council, 2016. 


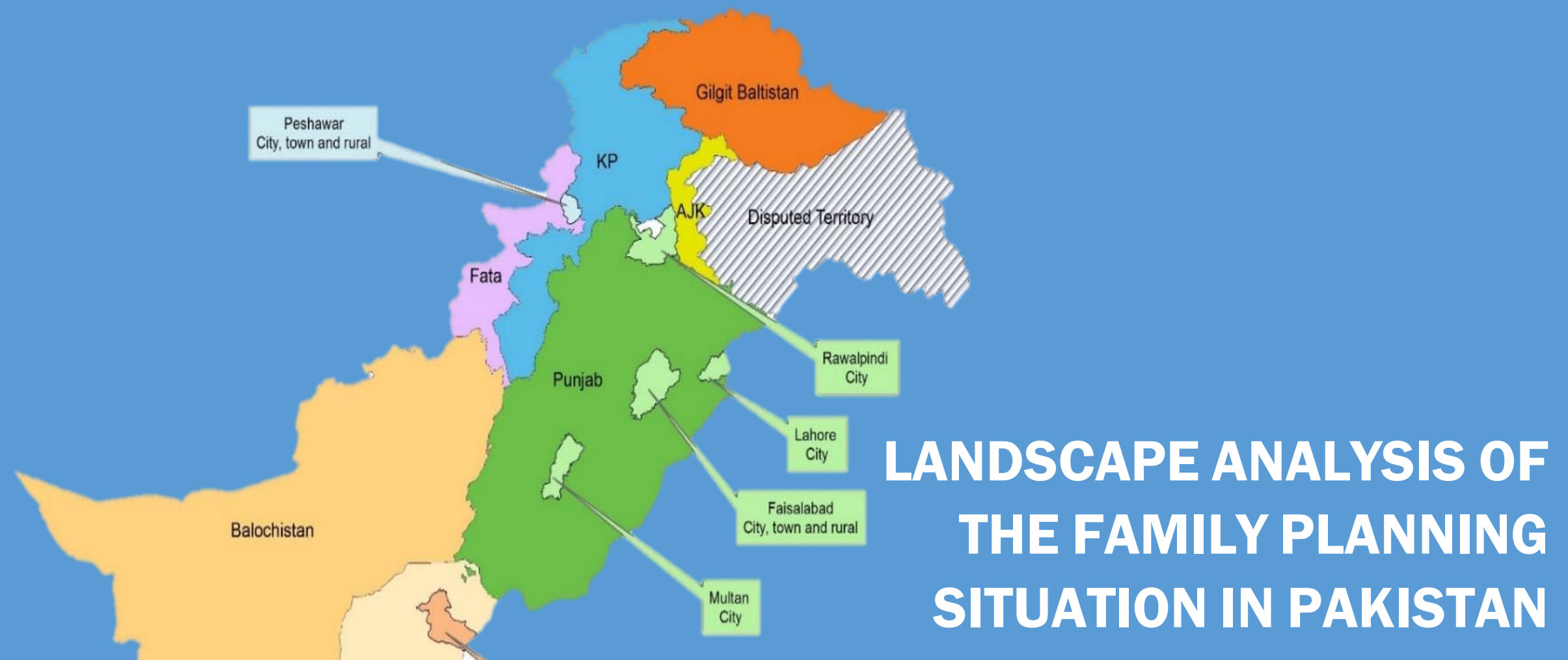

May 2016

DISTRICT PROFILE: LAHORE

BILL\& MELINDA

GATES foundation
POPULATION COUNCIL

Ideas. Evidence. Impact. 



\section{Background}

Lahore is situated in the northeastern part of Punjab. The district consists of ten administrative strata, including nine townships and one cantonment area; three townships-Data Ganj Buksh, Shalimar, and Samanabad- were the focus of this study (Figure 1).

Table 1 presents key demographic facts about the district and the three townships comprising the study area. Lahore has an estimated population of 9.5 million. ${ }^{1}$ Among the studied townships, Samanabad has the highest population followed by Data Ganj Buksh and Shalimar. Of the total 430 thousand married women living in the study area, 172 thousand live in Samanabad, 90 thousand in Shalimar, and 171 thousand in Data Ganj Buksh. The district's infant mortality rate is lower than other study districts.

Table 1: Demographics of Lahore district and study townships

\begin{tabular}{|l|l|l|l|l|}
\hline \multirow{2}{*}{ Demographics } & \multirow{2}{*}{$\begin{array}{l}\text { Lahore } \\
\text { District }\end{array}$} & \multicolumn{3}{|c|}{ Study Townships } \\
\cline { 3 - 5 } & $\begin{array}{l}\text { Data Ganj } \\
\text { Buksh Town }\end{array}$ & $\begin{array}{l}\text { Shalimar } \\
\text { Town }\end{array}$ & $\begin{array}{l}\text { Samanabad } \\
\text { Town }\end{array}$ \\
\hline $\begin{array}{l}\text { Total } \\
\text { population }\end{array}$ & $9,545,000$ & $1,070,000$ & 585,000 & $1,086,000$ \\
\hline $\begin{array}{l}\text { Women, } \\
15-49 \text { years }\end{array}$ & $2,453,000$ & 283,000 & 136,000 & 279,000 \\
\hline MWRA & $1,514,000$ & 171,000 & 90,000 & 172,000 \\
\hline $\begin{array}{l}\text { Literacy rate } \\
\text { (10 years } \\
\text { above)* }\end{array}$ & $80 \%$ & - & & - \\
\hline $\begin{array}{l}\text { IMR** } \\
\text { IMR }\end{array}$ & 53 & - & - & - \\
\hline $\begin{array}{l}\text { Source: Punjab Development Statistics 2015, * Pakistan Social and Living } \\
\text { Standards Measurement Survey (PSLMS) 2014-15, Multiple Indicator }\end{array}$ \\
\begin{tabular}{l} 
Cluster Survey Punjab (MICS) 2014 \\
\hline
\end{tabular}
\end{tabular}

Figure 1: Map of Lahore district showing townships covered

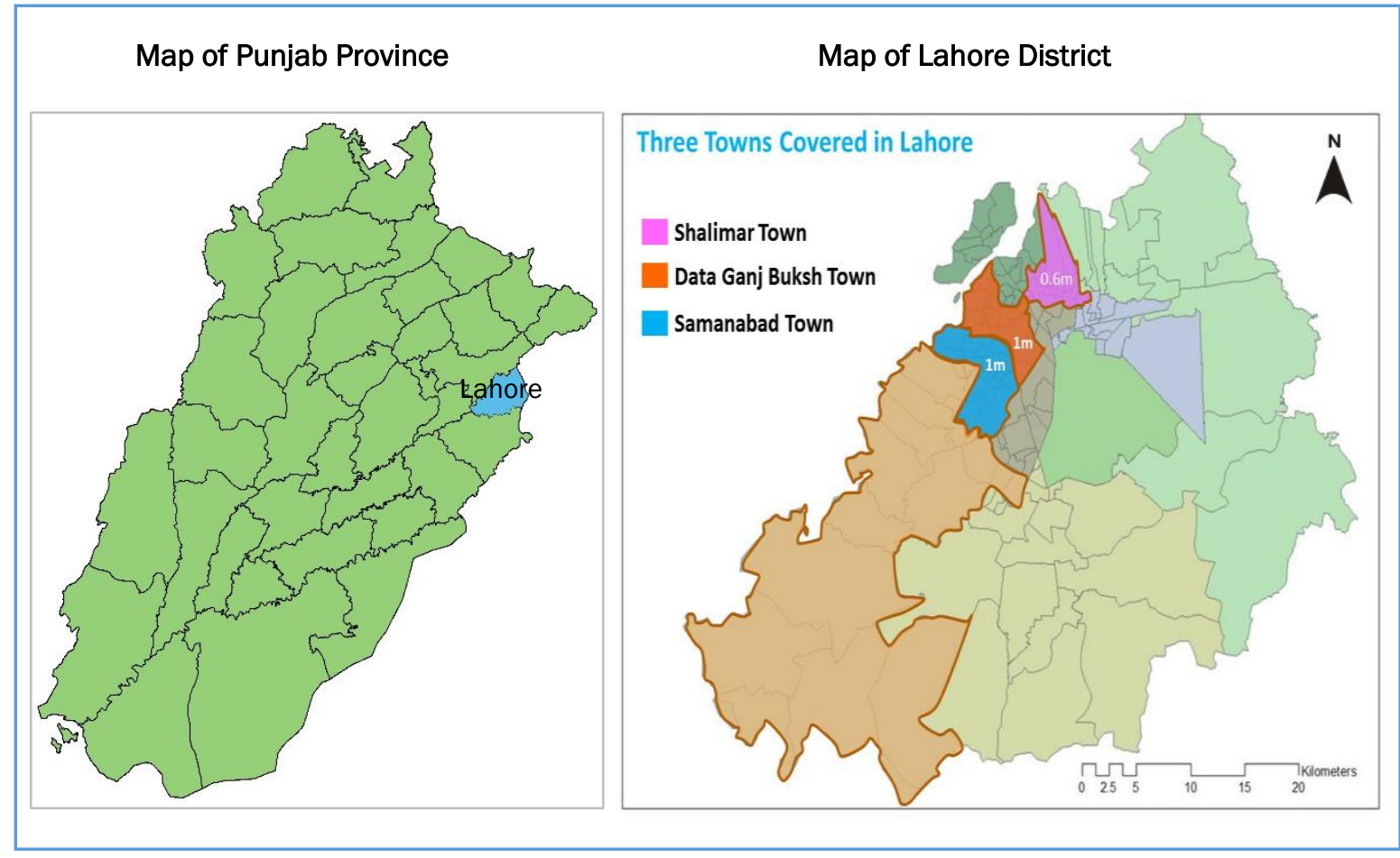

Note: The map shows the three towns within the district of Lahore where a census of health facilities and pharmacies was conducted during the landscape analysis. The towns included Samanabad, Shalimar, and Data Ganj Buksh.

Lahore's total fertility rate (TFR) is 3.21 . This is higher than the TFR in the three townships, which is lowest in Data Gunj Buksh (2.63), and highest in Samanabad (2.93), with Shalimar in the middle at 2.87 (Figure 2). ${ }^{2}$

1 Punjab Development Statistics 2015

2 Multiple Indicator Cluster Survey Punjab (MICS) 2011 
Figure 2: Total fertility rates in Lahore and three townships

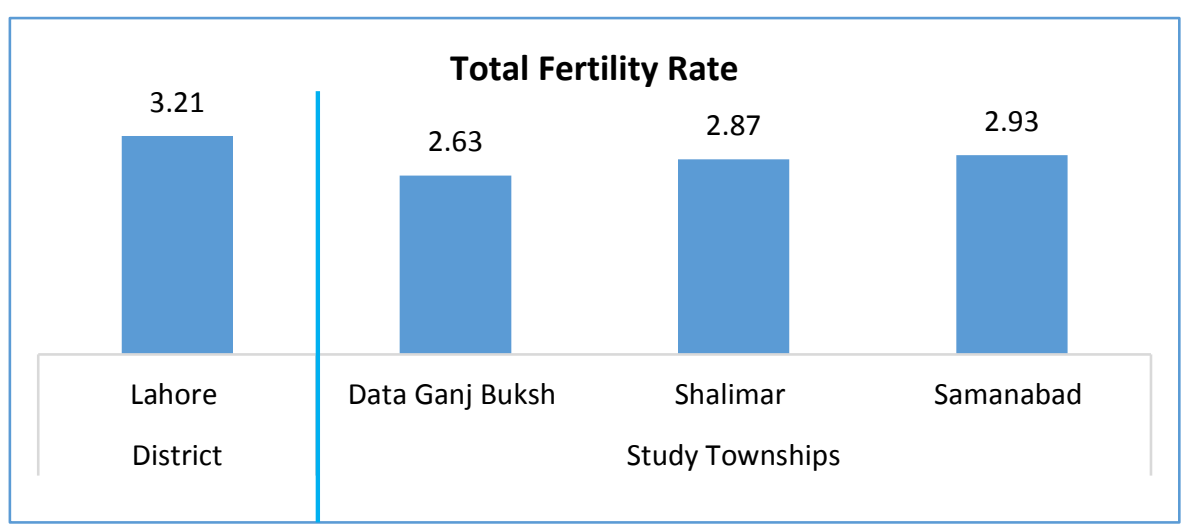

Source: Multiple Indicator Cluster Survey Punjab (MICS) 2011

\section{Contraceptive Use and Unmet Need}

Contraceptive use varies across the all three study townships (Figure 3). It is lowest in Shalimar Town (31.2\%) and highest in Samanabad Town (57.6\%). By method, modern use is also highest in Samanabad (55.2\%) and lowest in Shalimar (27.4\%), while traditional use is highest in Data Ganj Buksh (14.7\%) and lowest in Samanabad (2.3\%). Unmet need for family planning is negatively associated with contraceptive use; it is highest in Shalimar (29.5\%) and lowest in Samanabad (7.3\%).

Figure 3: Contraceptive use and Unmet Need in Lahore and Three Townships

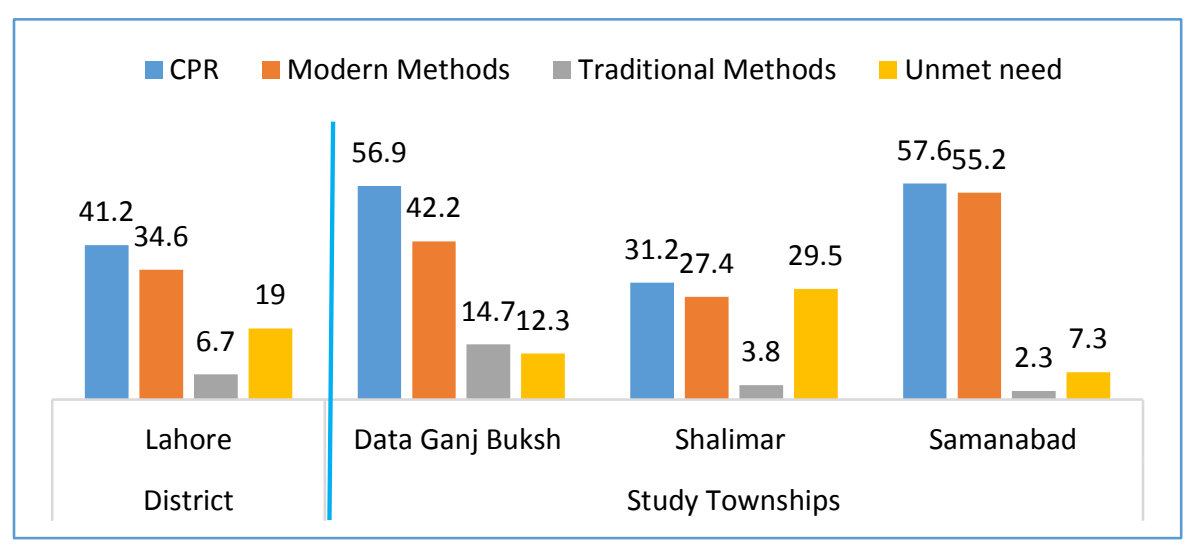

Source: Multiple Indicator Cluster Survey Punjab (MICS) 2011

\section{Use of Antenatal and Delivery Care Services}

The majority of women in Lahore sought antenatal health care from a skilled provider during their last pregnancy (90\%). ${ }^{3}$ Private hospitals or clinics are the major source of antenatal healthcare (47\%), followed by government health facilities (42\%). The majority of deliveries are institution based $(82 \%)$, mainly at private hospitals or clinics (45\%) and government facilities (37\%).

\section{Other Soclo-economic Indicators}

The literacy rate (10 years and above) in Lahore is as high as 80 percent. However, the female literacy rate is 5 percentage points lower than the male literacy rate $(82 \%)$. Interestingly the literacy rate among the reproductive aged women is as high as 81 percent. The majority of households own a television set (86\%). Mobile or landline phones are owned by the vast majority of households (97\%).

In terms of building materials, majority of the house roofs (82\%) are made of the more expensive reinforced cement concrete (RCC) or the reinforced brick concrete (RBC) and in fewer houses, the Garder (iron slabs)/T-Iron (13 percent) is used as the main roofing material. House walls are mainly constructed of burnt bricks. This reflects fairly good socio-economic conditions.

\section{Avallability of Health Facillties, Pharmacles and LHWs}

During the landscape analysis of family planning, a census of public and private health facilities and pharmacies was carried out in the Shalimar, Samanabad and Data Ganj Buksh townships in Lahore. Figure 4 shows the breakdown of public and private health facilities and pharmacies in the three towns. Within Shalimar Town, private facilities (43\%) are highest in number, followed by pharmacies (38\%) and Lady Health Workers (LHWs) (11\%). We find the same pattern in Samanabad Town (private facilities, 54\%; pharmacies, 33\%; LHWs, $7 \%$ ) and in Data Ganj Buksh Town (private facilities, 58\%; pharmacies, 28\%; LHWs, 11\%). Comparing the three towns, there are more private facilities in Samanabad, more pharmacies in Shalimar, and more LHWs in Data Ganj Bukhsh. Overall, private health facilities account for the largest share, followed by pharmacies, and LHWs. In comparison, presence of static facilities of the Department of Health (DoH) and Population Welfare Department (PWD) is quite low.

${ }^{3}$ Pakistan Social and Living Standards Measurement Survey (PSLMS) 2014-15 
Figure 4: Distribution of facilities and pharmacies in three towns of Lahore by sector, 2016

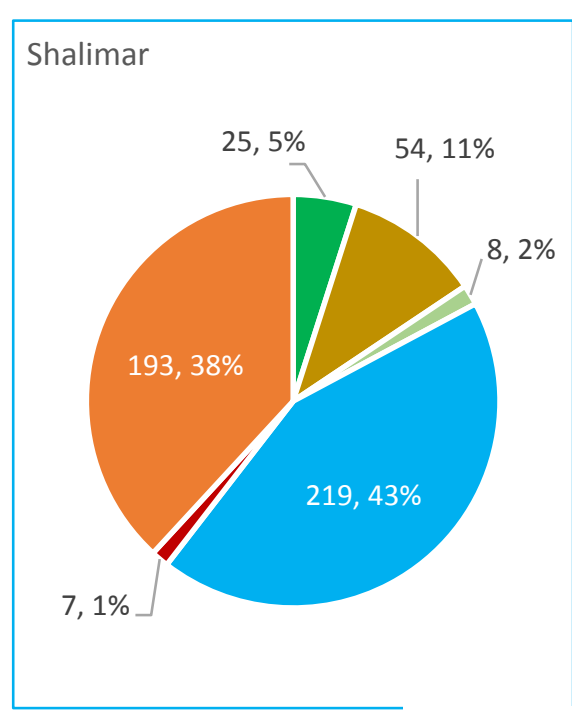

- $\mathrm{DoH}$

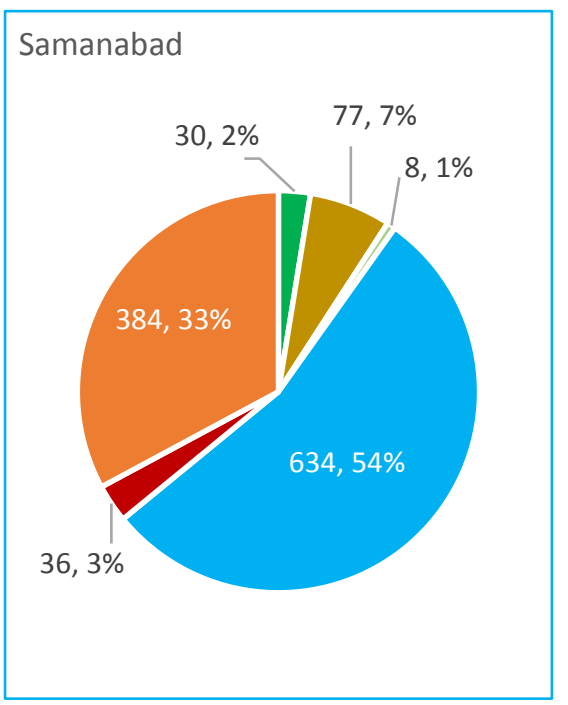

- LHWs $=$ PWD $=$ Private $\quad$ CMWs

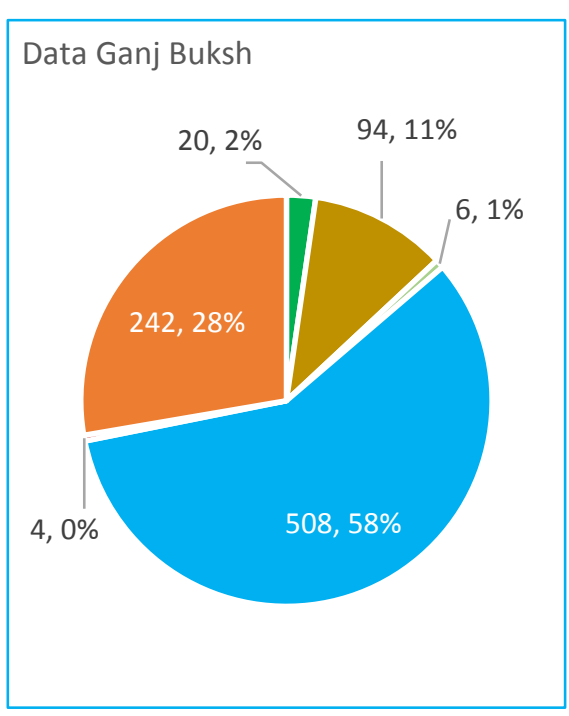

- Pharmacies
Buksh, most public facilities are present in nearly equal numbers (public hospitals, 27\%; $\mathrm{MCH}$ centers/maternity homes, 23\%; and FWCs, 19\%). Comparing the towns, there are more public hospitals in Data Ganj Buksh, more $\mathrm{MCH}$ centers/ maternity homes in Shalimar, and more dispensaries are more in the Samanabad town and FWCs are almost equal in numbers. PWD's Reproductive Health Service Centers (RHSC-A) and Family Health Centers (FHC) are present in Samanabad and Data Ganj Buksh, in smaller numbers.

\section{Distribution of Public Static Facilities by Cadre}

Figure 5 shows the distribution of static public health facilities in the Three Towns of Lahore. In Shalimar, Mother and Child health (MCH) centers/maternity homes are highest in numbers (52\%), followed by dispensaries (21\%) and PWD's Family Welfare Centers (FWCs) (24\%). In Samanabad, dispensaries are highest in number (39\%), followed by $\mathrm{MCH}$ centers/maternity homes (24\%), and public hospitals (16\%). In Data Ganj
Figure 5: Cadre-wise distribution of static public facilities in three towns of Lahore, 2016
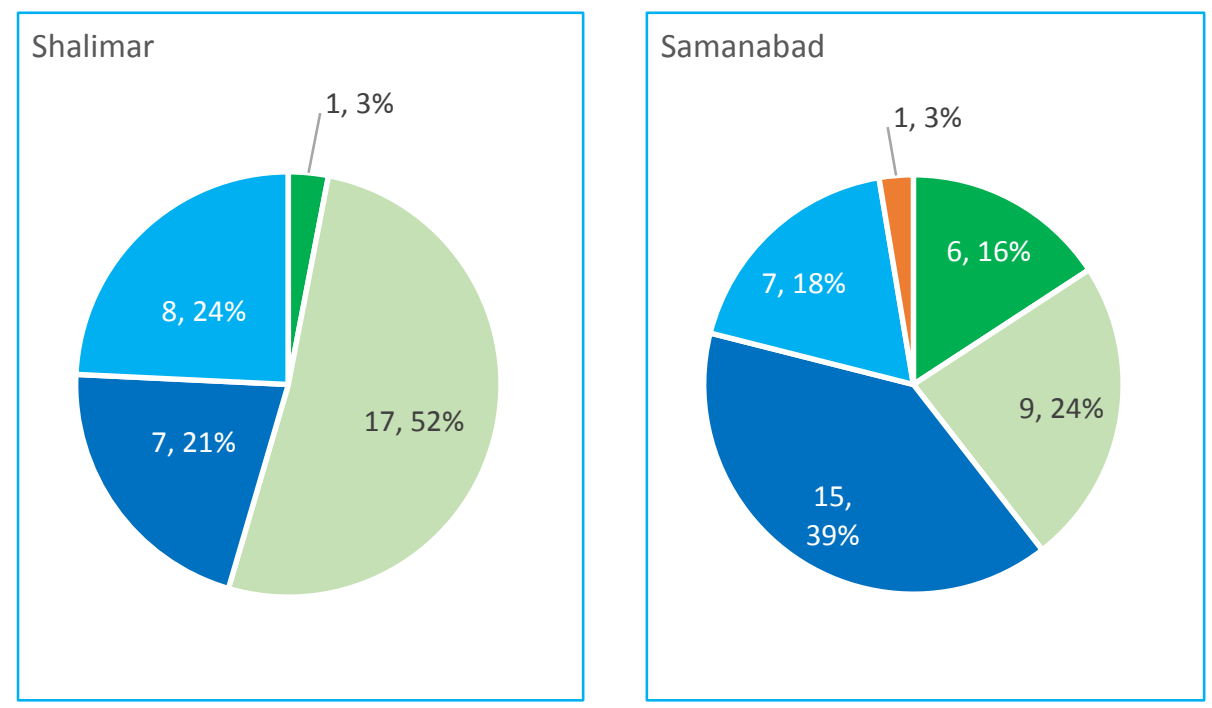

- Public Hospitals $=$ MCH Centers/Maternity Homes a Dispensaries a FWCs a RHSC-A/FHCs 


\section{Distribution of Private Facilities by}

\section{Cadre}

Figure 6 shows the distribution of private facilities in the Three Towns of Lahore. Homeopath/ hakeem clinics are largest in number $(55 \%$ in Shalimar, $56 \%$ in Samanabad, and 60\% in Data Ganj Buksh), followed by clinics of male doctors $(23 \%$ in Shalimar and Samanabad, and 22\% in Data Ganj Buksh), and private hospitals (9\% in Shalimar, 7\% in Samanabad and 5\% in Data Ganj Buksh). There are fewer clinics of female doctors in the three towns $(5 \%$ in Shalimar, 6\% in Samanabad and 7\% in Data Ganj Buksh), which collectively comprise only around 7 percent of private health facilities, and the presence of other private facilities is negligible.

\section{Provision of Speciflc Family Planning Methods by Sector}

Table 2 shows the proportion of different sectors providing specific family planning methods in the Three Towns of Lahore. Facilities of the Department of Health are providing most methods but the level of provision is quite low. Facilities of the Population Welfare Department are providing most methods. LHWs are almost fully providing condoms, pills, and the second/subsequent dose of injectables.
Figure 6: Cadre-wise distribution of private facilities in three towns of Lahore, 2016
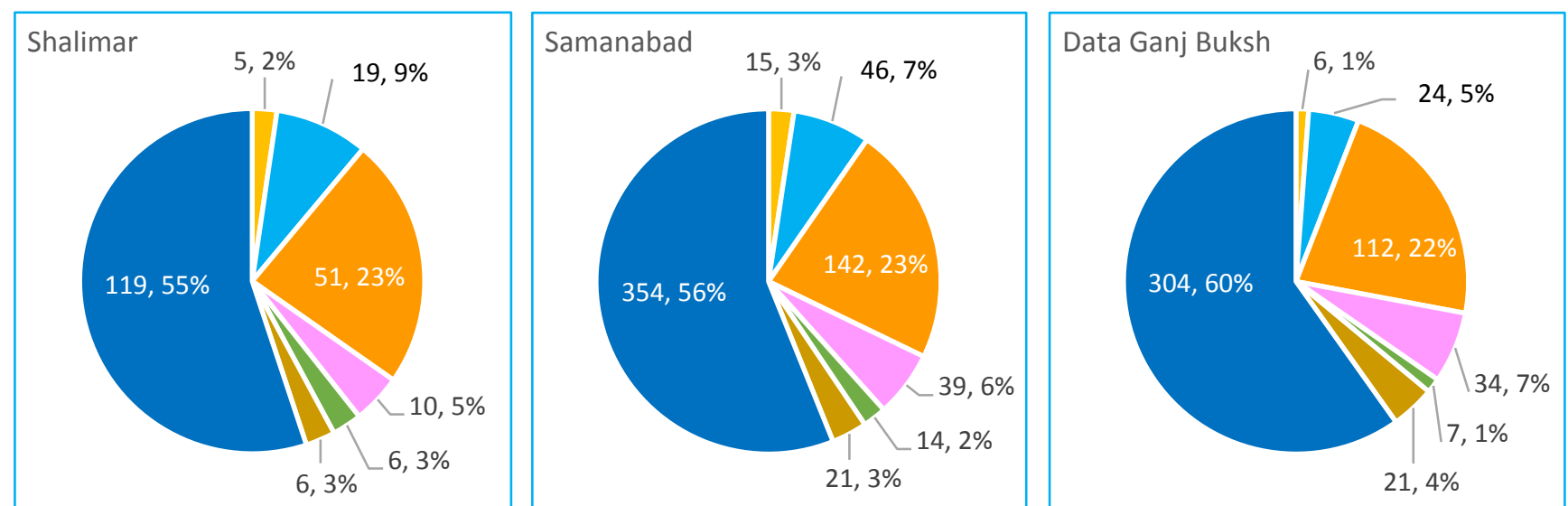

- Male Doctor Clinics

- Homeopath/Hakeem Clinics

Table 2: Provision of specific family planning methods in three towns of Lahore by sector, \%, 2016

\begin{tabular}{|c|c|c|c|c|c|c|c|c|c|c|c|c|c|c|c|c|c|c|c|c|c|c|c|c|c|c|c|}
\hline \multirow[b]{2}{*}{ Sector } & \multicolumn{3}{|c|}{ Condoms } & \multicolumn{3}{|c|}{ OCPs } & \multicolumn{3}{|c|}{ Injectables } & \multicolumn{3}{|c|}{ IUDs } & \multicolumn{3}{|c|}{ Implants } & \multicolumn{3}{|c|}{ ECPs } & \multicolumn{3}{|c|}{$\begin{array}{c}\text { Female } \\
\text { Sterilization }\end{array}$} & \multicolumn{3}{|c|}{$\begin{array}{c}\text { Male } \\
\text { Sterilization }\end{array}$} & \multicolumn{3}{|c|}{$\begin{array}{l}\text { Number of } \\
\text { Facilities/ } \\
\text { Pharmacies }\end{array}$} \\
\hline & T1 & $\mathrm{T} 2$ & T3 & $\mathrm{T} 1$ & $\mathrm{~T} 2$ & T3 & $\mathrm{T} 1$ & $\mathrm{~T} 2$ & T3 & $\mathrm{T} 1$ & $\mathrm{~T} 2$ & T3 & $\mathrm{T} 1$ & $\mathrm{~T} 2$ & T3 & $\mathrm{T} 1$ & $\mathrm{~T} 2$ & Т3 & $\mathrm{T} 1$ & $\mathrm{~T} 2$ & T3 & $\mathrm{T} 1$ & $\mathrm{~T} 2$ & T3 & $\mathrm{T} 1$ & T2 & T3 \\
\hline DoH & 24 & 30 & 20 & 36 & 33 & 25 & 68 & 33 & 25 & 64 & 30 & 25 & 8 & 7 & 10 & 16 & 20 & 20 & 100 & 60 & 100 & 0 & 14 & 0 & 25 & 30 & 20 \\
\hline PWD & 100 & 100 & 100 & 100 & 100 & 100 & 100 & 100 & 100 & 100 & 100 & 100 & 13 & 13 & 17 & 75 & 50 & 50 & 0 & 13 & 17 & 0 & 0 & 0 & 8 & 8 & 6 \\
\hline LHWs & 100 & 100 & 100 & 100 & 100 & 100 & 100 & 100 & 100 & NA & NA & NA & NA & NA & NA & NA & NA & NA & NA & NA & NA & NA & NA & NA & 54 & 77 & 94 \\
\hline Private & 2 & 6 & 1 & 5 & 10 & 5 & 10 & 12 & 6 & 10 & 12 & 5 & 2 & 2 & 1 & 3 & 9 & 1 & 75 & 62 & 33 & 38 & 38 & 20 & 219 & 634 & 508 \\
\hline Pharmacies & 96 & 74 & 49 & 96 & 71 & 41 & 84 & 47 & 27 & 75 & 37 & 23 & 0 & 0 & 0 & 93 & 66 & 44 & NA & NA & NA & NA & NA & NA & 193 & 384 & 242 \\
\hline
\end{tabular}

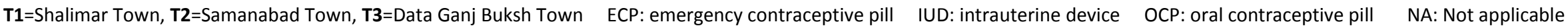




\section{Presence and Provision of FP Services/Products: A Comparlson}

Figures 7, 8 and 9 present pairs of maps showing the presence of public health facilities, private health facilities, and pharmacies, respectively, and also their status of provision of at least one family planning service/product by each category. Figure 7 shows that, collectively, only 64 percent of the 97 public health facilities are providing family planning services, although they are all mandated to provide this service

Figure 7: proportion of public static facilities providing at least one FP service in three towns of Lahore, 2016
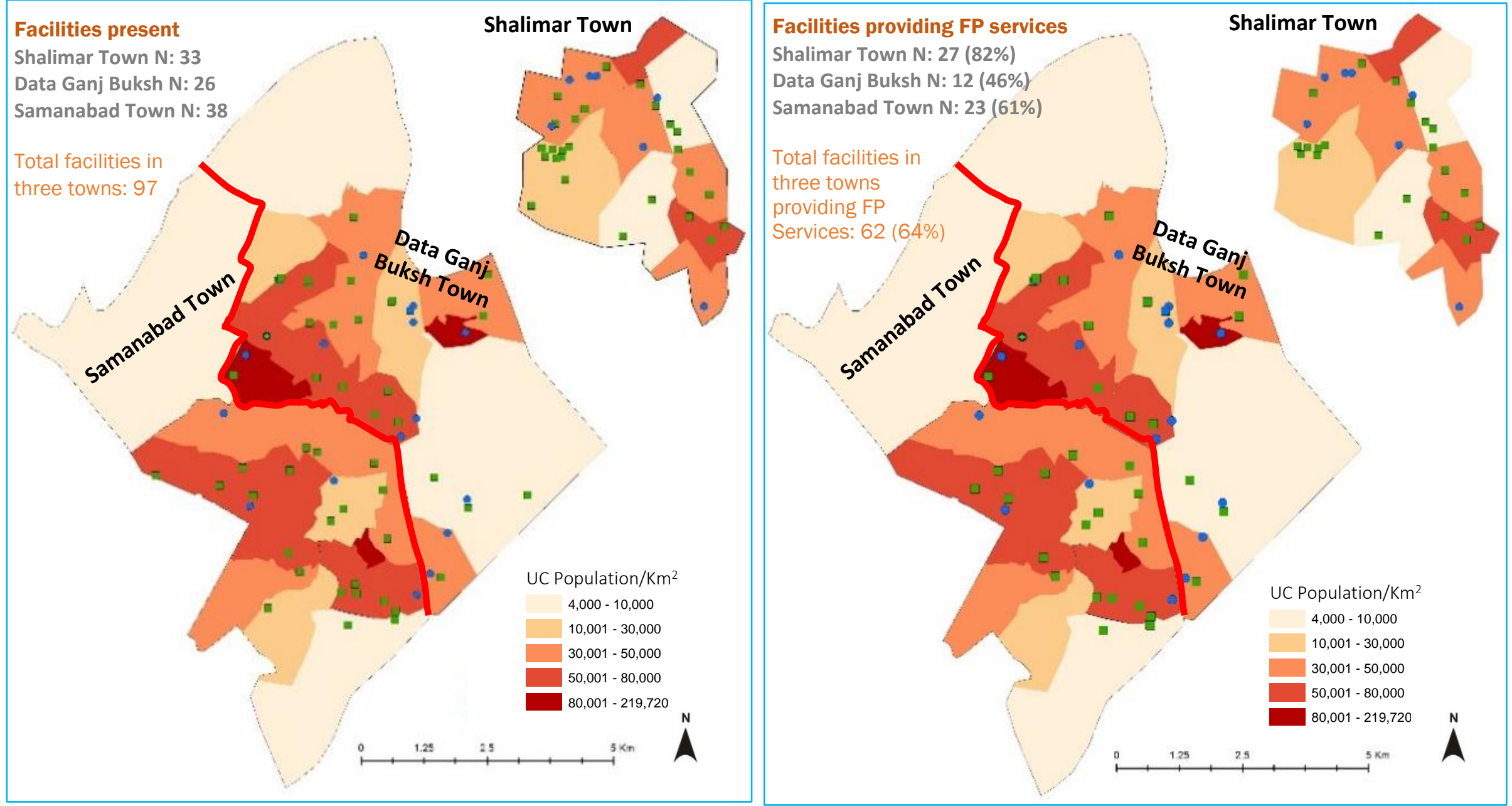

- Department of Health (DoH)

- Punjab Rural Support Programme (PRSP)

- Population Welfare Department (PWD) 
Among private health facilities, the proportion providing any family planning services drops to a very low 20 percent (Figure 8). But due to their greater numbers, more than four times as many private facilities are currently providing any family planning services as public facilities in the three townships of Lahore.

Figure 8: proportion of private facilities providing at least one FP service in three towns of Lahore, 2016
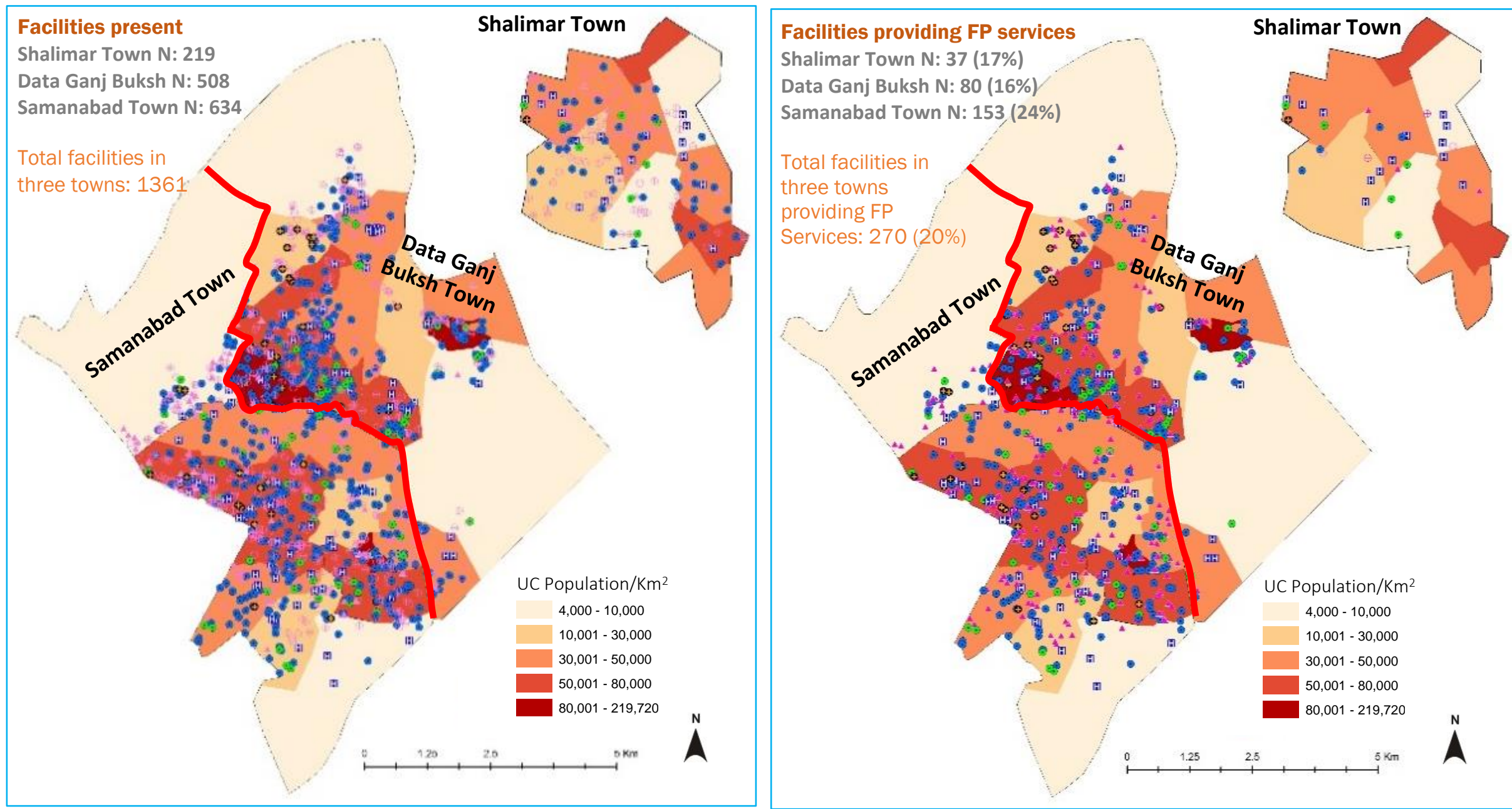

10 Private Hospitals

- Male Doctor Clinics

- LHV/Nurse/Midwife Clinics

- Female Doctor Clinics

\section{- Dispenser Clinics}

Homeopath/Hakeem Clinics 
Encouragingly, of the over 800 pharmacies present, 74 percent are selling at least one FP product (Figure 9).

Figure 9: Proportion of pharmacies selling at least one FP product in three towns of Lahore, 2016
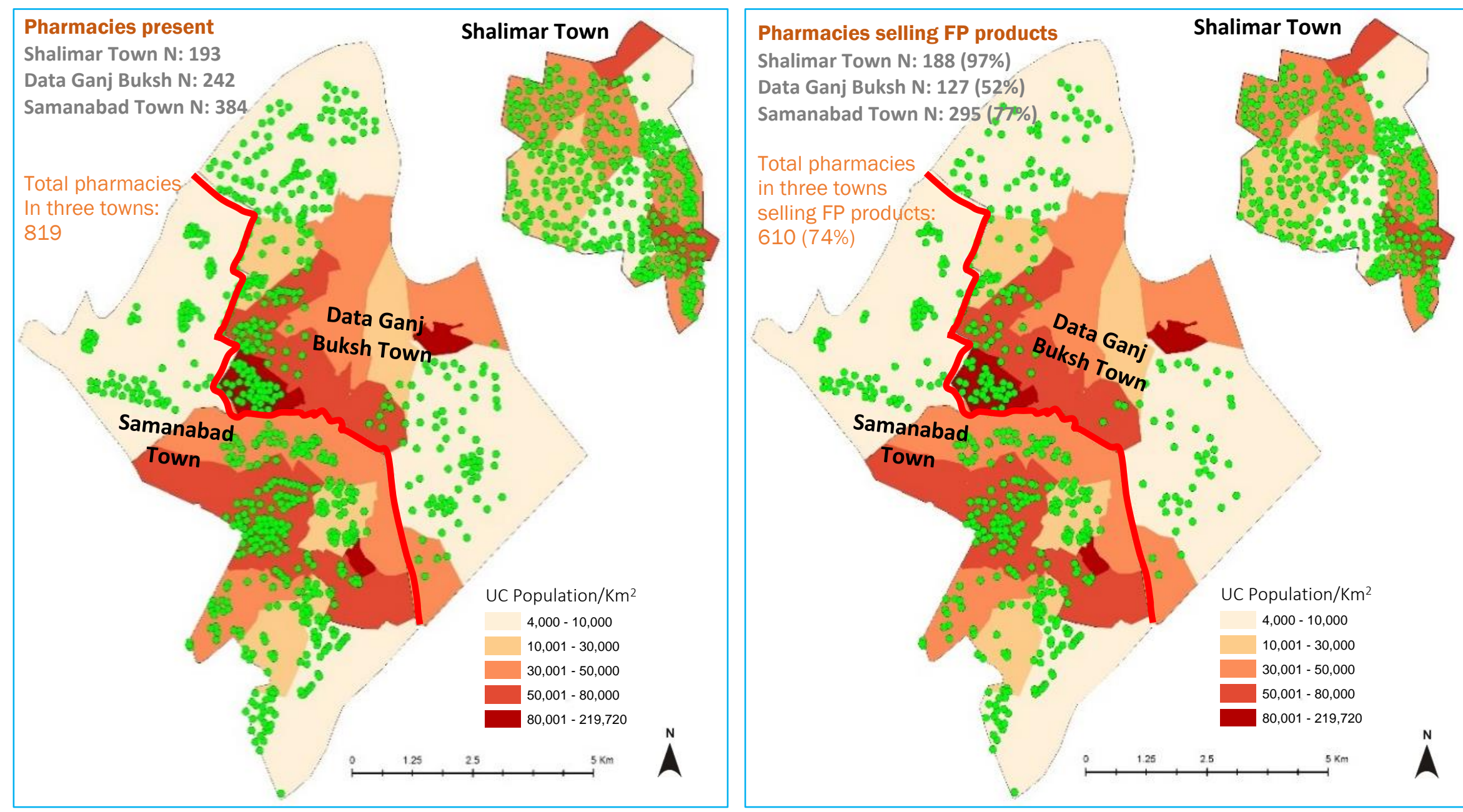


\section{Consumer Perspectives on Barriers to Use of Family \\ Planning}

During the landscape assessment, the study team collected the views of 100 men and women on family planning in the towns of Samanabad and Shalimar in Lahore. The interactions included 30 in-depth interviews (IDIs), with 18 women and 12 men, and 7 focus group discussions (FGDs) with men and women.

The two key barriers to use of family planning in the communities were lack of information and services, for men, and cost of services, for poor couples.

\section{Lack of information among men}

- This is a strong barrier for men, notwithstanding their urban environment.

- Men consider family planning a very private matter, and are reluctant to discuss it with other men.

- Men's main sources of information are their wives, who in turn are informed by LHWs or other women in the family or neighborhood.

- Educated men are more comfortable getting information from the Internet rather than discussing it in person; however, there could be gaps in the information they access.

- Men with low education have no direct source for information on family planning.

"I feel hesitant to discuss family planning with my friends, family and relatives." Male, Lahore city

"I don't discuss about this topic with friends. They feel embarrassed talking about this." Male, Lahore city

"There is lack of education in the area, people have no awareness about family planning, and they don't discuss it-it is a very rare occasion if we discuss it. Facebook, Twitter, and the Internet are common nowadays, but you cannot even talk about it with your brothers. People hesitate in this." Male, Lahore city
- Although the majority of men use condoms, they feel embarrassed purchasing them from shops.

"People feel shy getting the method (condoms). There should be some special code words and special centers for such things." Male, Lahore city

Difficulty in affording private services, among poor couples

- Cost of services is a less strongly reported barrier than information needs, but it affects poor users

- Despite having financial constraints, couples may be compelled to use private sources:

- Condom users may have to purchase the method from shops and pharmacies when LHWs' stocks run out, or when they want to use a better quality of condoms, which can be expensive

- Women prefer to get services from private facilities because they perceive their quality to be better; they arrange to pay for the higher costs

- Although they are required to provide free services and contraceptives, some LHWs charge fees for injectables; women are willing to pay this price because they get the service at their doorstep

- Treatment for management of side effects also imposes a financial burden that can be hard to manage.

"I arranged the money because you have to manage. I used other methods but they did not suit me so finally I got the same method (IUD) from a private clinic and I paid 250 rupees." Female, Lahore city

"I got injection from the Baji (LHW) of our area. She provides pills free of cost and charges 100 rupees for the injection; this amount is manageable. Earlier it was hard to afford but now I can manage because I do some stitching work at home." Female, Lahore city 


\section{District specific Donors, Projects and Implementing partners}

\begin{tabular}{|c|c|c|}
\hline Donor & Program/Project Title & Implementing Partner \\
\hline DFID & $\begin{array}{l}\text { Delivering Reproductive Health Results (DRHR), } \\
\text { 2012-2017 }\end{array}$ & $\begin{array}{l}\text { Population Services International (PSI)/Greenstar } \\
\text { Social Marketing (GSM) } \\
\text { Marie Stopes International: Reproductive Health } \\
\text { DKT International/Pakistan }\end{array}$ \\
\hline \multirow{2}{*}{$\begin{array}{l}\text { Bill and Melinda Gates } \\
\text { Foundation }\end{array}$} & $\begin{array}{l}\text { Building Blocks for Family Planning in Pakistan - Developing a Costed } \\
\text { Implementation Plan for Sindh and Punjab, 2013-2015 }\end{array}$ & Pathfinder International \\
\hline & $\begin{array}{l}\text { Landscape Analysis of Family Planning in Pakistan, } \\
\text { 2015-2016 }\end{array}$ & Population Council \\
\hline \multirow{2}{*}{$\begin{array}{l}\text { The David \& Lucile } \\
\text { Packard Foundation }\end{array}$} & Achieving MDG5 - Continuing Momentum, Building Champions, 2012-2015 & Shirkat Gah Women Resource Centre \\
\hline & Strengthening and Sustaining Postpartum Family Planning in Pakistan, 2013-2015 & JHU - JHPIEGO \\
\hline USAID & DELIVER Project, 2008-2016 & $\begin{array}{l}\text { Planning Commission of Pakistan } \\
\text { Ministry of Health } \\
\text { Provincial and regional departments of health and } \\
\text { population } \\
\text { UNFPA } \\
\text { NGOs }\end{array}$ \\
\hline \multirow[b]{2}{*}{ UNFPA } & $\begin{array}{l}\text { Capacity Building of Female service providers Enhanced in Family Planning, 2014- } \\
2017\end{array}$ & $\begin{array}{l}\text { Population Welfare Departments } \\
\text { MNCH Programs } \\
\text { LHWs Program }\end{array}$ \\
\hline & $\begin{array}{l}\text { Advocacy for Universal Access to Reproductive Health and to Integrate in } \\
\text { Provincial Health Policies, Plans and Budgetary Frameworks, 2012-2017 }\end{array}$ & $\begin{array}{l}\text { Population Welfare Departments } \\
\text { Population Council } \\
\text { Pathfinder } \\
\text { Ministry of National Health Services, Regulations and } \\
\text { Coordination }\end{array}$ \\
\hline WHO & $\begin{array}{l}\text { Providing Technical Assistance to the Country for the Development of a Unified } \\
\text { Care Providers Manual on FP based on the WHO Handbook on FP }\end{array}$ & $\begin{array}{l}\text { Ministry of National Health Services Coordination and } \\
\text { Regulation } \\
\text { MNCH programs } \\
\text { UNFPA, Population Council, GIZ, USAID, etc. }\end{array}$ \\
\hline $\begin{array}{l}\text { Large Anonymous Donor } \\
\text { (LAD) }\end{array}$ & $\begin{array}{l}\text { Increasing Access to and Use of Long Term Methods of FP and PAC Services in } \\
\text { Pakistan, 2014-16 }\end{array}$ & Greenstar Social Marketing \\
\hline
\end{tabular}

